\title{
Perspectives of anaerobic decomposition of biomass for sustainable biogas production: A Review
}

\author{
S. Indran ${ }^{1, *}$, D. Divya ${ }^{2}$, Sanjay Mavinkere Rangappa ${ }^{3}$,Suchart Siengchin ${ }^{3}$, P. Merlin Christy ${ }^{4}$, L.R.Gopinath ${ }^{4}$ \\ ${ }^{1}$ Rohini College of Engineering and Technology, Palkulam-629401, Kanyakumari District, TN, India. \\ ${ }^{2}$ Research and Development Department, Pinnacle Bio-Sciences, Kanyakumari-629701, TN, India. \\ ${ }^{3}$ Natural Composites Research Group Lab, Department of Materials and Production Engineering, The Sirindhorn International Thai- \\ German Graduate School of Engineering, King Mongkut's 13 University of Technology North Bangkok, Bangkok-10800, Thailand. \\ ${ }^{4}$ Vivekanandha College of Arts and Sciences for Women, Tiruchengode-637205, Namakkal, TN, India.
}

\begin{abstract}
Biogas production from biomass is an eco-friendly approach that offers renewable energy generation, waste recycling, biofertilizer production along with maintaining environmental quality. Anaerobic decomposition is a familiar practice used for biogas production in worldwide, whereas only few substrates were convenient for attaining desired methane concentration in biogas. Hence, further advancements are necessary for the exploration and utilization of various complex organic materials for the purpose. This article gives a clear outlook on potential of various biomass for biogas production, necessity of pretreatment, applicability of microbial/enzyme addition, maintenance of various process parameters, formulation of suitable digester designs and future scope of this area. The livestock wastes and agricultural wastes possess high energy generation potential $(71 \%)$ and sustainable utilization of such wastes are admirable to commercialize biogas production in future. Hence, selection of biomass through biochemical methane potential (BMP) analysis and biomass pretreatment prior to anaerobic decomposition is adequate to improve the quality and quantity of generated biogas. Addition of effective microorganisms or respective enzymes along with the employment of suitable bioreactors, are other perspectives to enhance decomposition. The single-stage and multi-stage systems possess much attention than other types of reactors since that offers accurate process management at four different stages of decomposition. Moreover, the maintenances of optimum $\mathrm{pH}$, temperature, volatile fatty acids, carbon/nitrogen ratio, etc. are crucial to evade system unsteadiness during decomposition. Since comprehensive mathematical models are appropriate to make the anaerobic decomposition process economically feasible and advancement with these forecasts are adequate to commercialize this technology in the future.
\end{abstract}

Keyword. Biomass, Anaerobic decomposition, Biogas, Methane, Pretreatment

\section{Introduction}

Though many resources exist to meet energy demand, bioenergy draws more attention since it reduces the overreliance of fossil fuel, in addition to partake carbon neutral property [1]. Bioenergy is a form of renewable energy derived from various organic materials known as biomass and it can be used to make transportation fuels with appropriate treatments. According to Mercom India Solar Project Tracker (2020), the cumulative power capacity of renewable energy is $36.2 \%$ (Figure 1). Among various renewable energy sources, the power generated from bio-based materials accounts for $2.7 \%$ [2]. Table 1 demonstrates biofuels obtained from discrete feed stocks, specific conversion processes, and the energy yield from various sources. Among various biofuels, biogas produced through anaerobic digestion is a fascinating approach due to its certain criteria's such as waste management, skill less small-scale production, costeffectiveness and multiple-benefits.

Anaerobic digestion is the historically recognized method for cleansing of various organic wastes. It was recognized in the $17^{\text {th }}$ century by Robert Boyle and
Stephen Hale from the sediments of lake streams. Later, the presence of methane in biogas was identified by Humphry Day in the year 1808 [3]. The first anaerobic digester in India was built in Bombay as a part of promoting renewable energy technology [4]. This technology has gained attention over other energy generation technologies due to its multiple benefits such as energy and heat generation, waste recycling, biofertilizer production, environmental protection from pollutants, greenhouse gas reduction, etc. [5]. Even though the improper management of environmental parameters, the complexity of substrates, the efficiency of microorganisms, and the unsteadiness of bioreactors were reported as the drawbacks that inclined the researchers to improve the biogas productivity through various prospects.

Biogas is composed of methane, carbon dioxide, nitrogen, hydrogen, hydrogen sulphide and oxygen, and the typical biogas concentration is represented in table 2 [6]. Where, methane is the flame source, and lower methane content impedes the usage of biogas for commercial purposes [7]. The typical methane

* Corresponding author: indransdesign@ gmail.com 
concentration was reported to be 50-73\%, which is comparatively lower than that of LPG and CNG with a high methane concentration of around 95-99\%. Hence, a deep understanding of the rate-limiting factors of biogas production is adequate and contemporary research and development of various prospects of anaerobic decomposition might significantly improve the methane concentration of biogas to accomplish its industrialization.

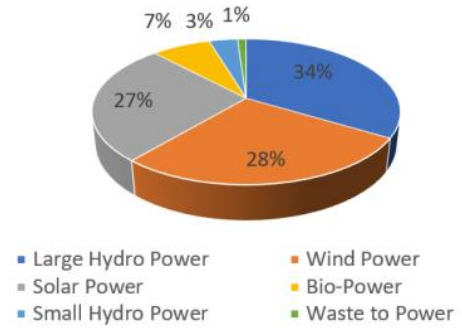

Fig. 1. Contribution of various renewable energy sources in overall production rate $(36.2 \%)$ (2020)

Table 1. Energy production potential of various biofuels.

\begin{tabular}{|c|c|c|c|}
\hline Biofuels & Feedstocks & Process & Energy yield \\
\hline \multirow{3}{*}{ Biohydrogen } & $\begin{array}{l}\text { Synthetic } \\
\text { waste } \\
\text { water }\end{array}$ & $\begin{array}{c}\text { Photo } \\
\text { fermentation }\end{array}$ & $3.6-7.9 \mathrm{~L} / \mathrm{L} / \mathrm{d}$ \\
\hline & $\begin{array}{c}\text { Cellulose } \\
\text { based } \\
\text { biomass }\end{array}$ & $\begin{array}{c}\text { Dark } \\
\text { anaerobic } \\
\text { fermentation }\end{array}$ & $12.2 \mathrm{~mol} \mathrm{H}_{2} \mathrm{Kg}^{-1}$ \\
\hline & $\begin{array}{c}\text { Macroalga } \\
1 \text { biomass }\end{array}$ & $\begin{array}{c}\text { Microbial } \\
\text { electrolysis }\end{array}$ & $74.5 \mathrm{ml} / \mathrm{g} \mathrm{COD}$ \\
\hline \multirow{4}{*}{ Biodiesel } & Soybean & $\begin{array}{c}\text { Transesterifi } \\
\text { cation }\end{array}$ & $95 \%$ at $65^{\circ} \mathrm{C}$ \\
\hline & $\begin{array}{c}\text { Rapeseed } \\
\text { oil }\end{array}$ & $\begin{array}{l}\text { Transesterifi } \\
\text { cation }\end{array}$ & $95 \%$ \\
\hline & $\begin{array}{l}\text { Unrefined } \\
\text { Palm Oil }\end{array}$ & $\begin{array}{c}\text { Transesterifi } \\
\text { cation }\end{array}$ & $90.4 \%$ \\
\hline & $\begin{array}{c}\text { Microalga } \\
\mathrm{e}\end{array}$ & $\begin{array}{l}\text { Transesterifi } \\
\text { cation }\end{array}$ & $12.03 \mathrm{~g} \mathrm{~m}^{-2} \mathrm{day}^{-1}$ \\
\hline \multirow{2}{*}{ Bioethanol } & $\begin{array}{c}\text { Sugarcane } \\
\text { bagasse }\end{array}$ & $\begin{array}{c}\text { Sugar } \\
\text { fermentation }\end{array}$ & $6.83 \pm 0.07 \%$ \\
\hline & $\begin{array}{c}\text { Corn stalk } \\
\text { juice }\end{array}$ & $\begin{array}{c}\text { Sugar } \\
\text { fermentation }\end{array}$ & $6.01 \%(\mathrm{v} / \mathrm{v})$ \\
\hline \multirow{4}{*}{ Biogas } & Cow dung & $\begin{array}{c}\text { Anaerobic } \\
\text { digestion }\end{array}$ & $64 \%$ \\
\hline & $\begin{array}{c}\text { Agro- } \\
\text { industrial } \\
\text { wastes }\end{array}$ & $\begin{array}{c}\text { Anaerobic } \\
\text { digestion }\end{array}$ & $6.55 \mathrm{dm}^{3} / \mathrm{kg}$ \\
\hline & $\begin{array}{c}\text { Agricultur } \\
\text { al wastes }\end{array}$ & $\begin{array}{c}\text { Anaerobic } \\
\text { digestion }\end{array}$ & $500 \mathrm{~cm}^{3}$ \\
\hline & $\begin{array}{c}\text { Househol } \\
\text { d waste }\end{array}$ & $\begin{array}{c}\text { Anaerobic } \\
\text { digestion }\end{array}$ & $73 \%$ \\
\hline
\end{tabular}

The current understanding of biomass conversion into biogas through anaerobic decomposition is fascinated by four steps such as hydrolysis, acidogenesis, acetogenesis and methanogenesis. An outline of the anaerobic digestion process is depicted in figure 2 .
Table 2. Composition of biogas [6]

\begin{tabular}{|c|c|}
\hline Composition & Percentage (\%) \\
\hline Methane & $50-75$ \\
\hline Carbon dioxide & $25-50$ \\
\hline Nitrogen & $0-10$ \\
\hline Hydrogen sulfide & $0-3$ \\
\hline Hydrogen & $0-2$ \\
\hline Oxygen & $0-2$ \\
\hline
\end{tabular}

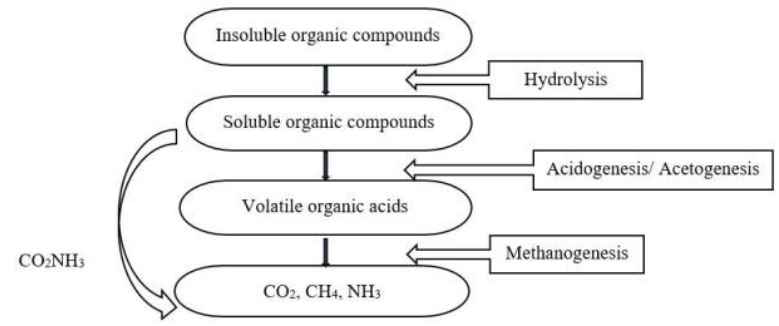

Fig. 2. Outline of the anaerobic decomposition process

The first rate-limiting stage is hydrolysis, where the complex organic materials (insoluble) are converted into simpler in line with this, acetogenesis plays a crucial role in converting long-chain fatty acids obtained by acidogenesis into acetate and $\mathrm{CO}_{2}$. Finally, the acetate and $\mathrm{CO}_{2}$ are converted to methane through methanogenesis [8]. The mechanism of bioconversion of organic materials during decomposition process is demonstrated in figure 3. There were several factors that influence the decomposition process with respect to different stages, biomass feedstock, type of bioreactors, etc. In this context, this article discusses the factors that remote the degradation of biomass and further prospects for enhancing biogas production with various aspects.

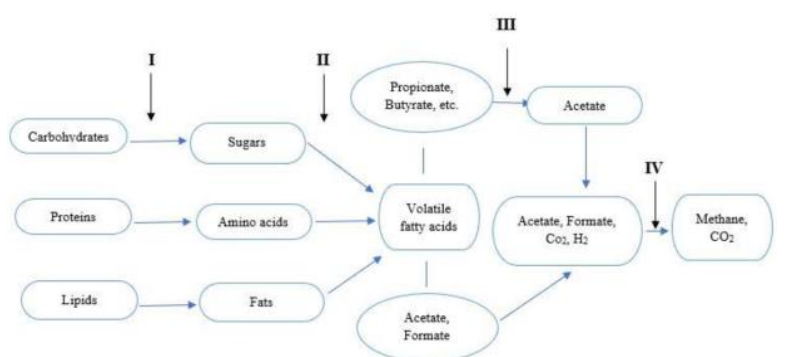

Fig. 3. Biochemical mechanism behind anaerobic decomposition process. I-Hydrolysis, II- Acidogenesis, IIIAcetogenesis, IV- Methanogenesis

\section{Potential of biomass for biogas production}

Biomass is mainly composed of cellulose, hemicellulose, lignin, starch, proteins, lipids and some organic and inorganic components. Cellulose is a polysaccharide composed of D-glucose units with $\beta$-1,4-glycosidic bonds [2]. Biogas can be produced from various cellulosic/ 
lignocellulosic biomass through the decomposition process. During the initial stage of degradation, the cellulose present in the feedstock is converted to Dglucose. Microbial enzymes can degrade cellulose, in fact, different microbial enzymes are required for diverse stages of anaerobic decomposition and their action is substrate specific [9]. Hemicellulose is a polymer of Dxylose, which is shorter than the cellulose chain. It can more easily break down than cellulose and soluble in alkaline solution. Lignin is a complex polysaccharide than other biomass constituents and the primary function of lignin is to give mechanical strength and protection to biomass in its native state. Microorganisms or chemicals cannot quickly degrade lignin due to their complex nature. Starch is another polysaccharide composed of D-glucose with $\alpha$-glyosidic bonds, which are water-soluble in contrast to cellulose. Another type of organic compound is proteins, which are composed of amino acids. Proteins are the nutritive source in biomass along with other organic and inorganic components [10]. Besides, lipids also contribute a prominent part of biomass that possess high calorific value compared with carbohydrates and proteins present in it.

Since biomass is an abundant resource of energy deriving components that apposite for biogas production. The biomass had been considered as the primary source of energy in the form of firewood and charcoal in the $19^{\text {th }}$ century. Consequently, it was replaced with coal and oil during the $20^{\text {th }}$ century. However, the potential of biomass for biogas production is extensively established during the $21^{\text {st }}$ century. Based on the source from where biomass obtained, it is characterized into three conventional biomass resources, biomass wastes and plantation biomass (Figure 4). The conventional biomass sources include agriculture, forestry, fishery and livestock. The biomass wastes or derivatives mainly include agricultural and livestock wastes. The aquatic, herbaceous and forestry biomass contributes to plantation biomass.

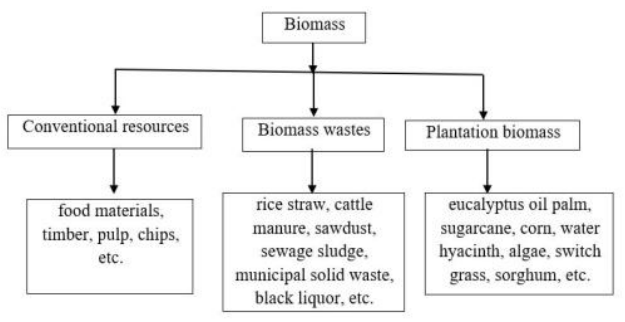

Fig. 4. Characterization of biomass

An assessment of biomass production showed that 1800 billion tons of total world biomass hosted on the ground and 4 billion tons presented in the ocean [10]. The ground biomass can provide 33,000 EJ, which can meet the total energy consumption of the world once it used in an accessible form. There are three significant sources of biomass energy that were established worldwide as livestock biomass, agricultural biomass and forestry biomass, and are illustrated in figure 5. In which, agricultural wastes (37\%) contributes to prominent energy generation, compared to livestock wastes (34\%) and forestry wastes (29\%) [10]. Moreover, biomass-based energy production has been recognized as a thriving prospect to enhance energy generation at this energy demanding current scenario [11].

The biomass utilized for biogas production is limited as compared to the total amount of biomass available in the world. Among the agricultural biomass, rice contributes the principal source, followed by wheat and maize confer the massive production in world wide. The availability of bagasse was higher than the other agricultural biomass. Since the utilization of agricultural biomass for energy production is not yet industrialized due to some concerns. Among livestock biomass, cattle dung (22 EJ) contributes the most substantial part, which accounts that cattle dung is the primary source of biomass available in the world for bioenergy production. Followed by poultry waste and sheep waste are accessible substantially. Forestry biomass represents the most available industrial logs, fuel $\operatorname{logs}$ and wood wax. Additionally, the availability ratio for agricultural biomass and livestock were $25 \%$ and $12.5 \%$. The highest availability ratio was noted for industrial logs were $75 \%$. Overall, the utmost availability is reported for industrial logs (15 EJ) (Figure 6) [12]. Although, further advancements are necessary to utilize wide substrate and thereby to enhance biomass-based energy generation policies in the future.

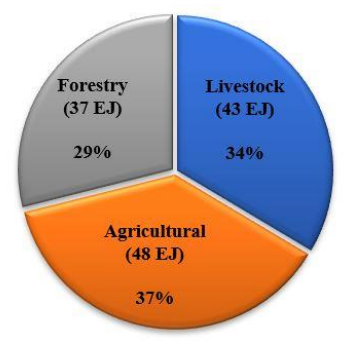

Fig. 5. Energy generation potential of biomass resources

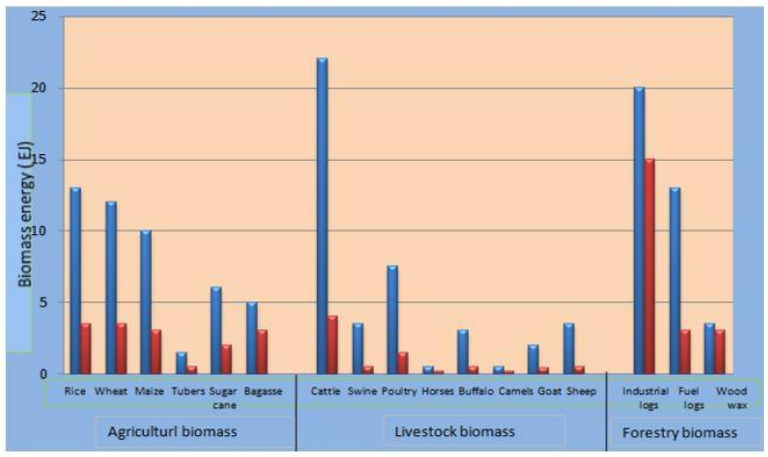

Fig. 6. Presence of biomass in the world and its availability [8]

\section{Biomass selection criteria and pretreatment}

The bio-methanation potential of each substrate is based on its carbohydrates, proteins, and lipids content. It is essential to delineate the chemical composition of the substrates prior to anaerobic decomposition in course to offer absolute decomposition. The biochemical methane 
potential (BMP) of the substrate to be statistically analysed in order to predict the potentiality of the substrate for the biogas production process. At the same time, the substrate availability, easy handling, low complexity, optimum carbon/nitrogen $(\mathrm{C} / \mathrm{N})$ ratio and moderate operational conditions are the other criteria to be taken in account for the selection of biomass for biogas production. Thus, the selection of materials based on biochemical methane potential of substrates and other relevant criteria could improve biogas production to a large extent [13].

The hydrolysis is the rate-limiting stage of biogas production, which largely influences the overall production process. Generally, particle size, age of the material, the composition of the feedstock, etc. are the factors that impact substrate degradation [14]. Most of the microbial enzymes cannot attack lignocellulose present in the complex organic materials. Lignocellulosic materials possess high nutrient content compared to simpler materials; which can be used as potential substrates for biogas production once it is pretreated. Pretreatment is necessary to accelerate the degradation potential of various complex solid substrates [15]. Pretreatment by hydrolytic bacteria made avail simpler organic compounds for other groups of bacteria. Physical, chemical, physico-chemical and biological treatment methods are available for pretreatment. Though, pretreatment of biomass before microbial degradation shows a significant effect on improving biogas production, as demonstrated in figure 7. Biological pretreatment paid more attraction than other methods due to its effectiveness and simple, effortless nature [16]. There were some disadvantages reported in the case of physical, chemical and physico-chemical pretreatments. The physical treatment is aligned with the particle size of the feedstock, while chemical treatment causes the excess release of volatile fatty acids that will lead to process inhibition. Furthermore, physical and chemical treatments are expensive and require high energy [17]. The costeffectiveness, low energy consumption, higher substrate specificity and environmental friendliness are the outcomes of biological pretreatment [18]. Based on the nature of pretreatment, biological treatment can be categorized as aerobic microbial pretreatment and anaerobic microbial pretreatment. In aerobic pretreatment, naturally occurring mixed cultures that produce cellulase, xylanase and laccase are used to degrade cellulose, hemicelluloses, lignin, respectively.

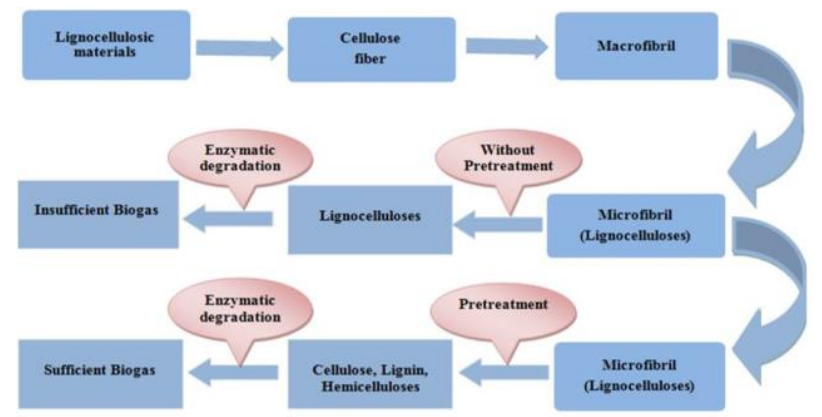

Fig. 7. Biogas production through pre-treatment
During anaerobic microbial treatment, a preacidification step offers an increased degradation rate by providing optimum conditions for hydrolytic enzymes [19]. Several fermentative bacteria (Pseudomonas spp., Cellulomonas spp., Streptomyces spp., Bacillus spp. and Actinobacteria spp.) and white-rot fungi (Coriolus spp., Aspergillus spp., Trichoderma spp., Phanerochaete spp. and Penicillium spp.) are preferred for productive pretreatment purposes [20,21]. Nevertheless, further advancement is admirable to find out potential microbes for pretreatment or absolute deployment of available microbes by providing optimum conditions for its enzyme production and activity.

\section{Role of microbes in anaerobic decompositions}

There are four different phases are involved in anaerobic digestion such as hydrolysis, acidogenesis, acetogenesis and methanogenesis. The hydrolytic, acidogenic, acetogenic and methanogenic bacteria are involved in the hydrolysis, acidogenesis, acetogenesis, methanogenesis stages, respectively. Different stages of anaerobic decomposition with probable microbes for each step are presented in table 3. The effectiveness of microbes involved in anaerobic decomposition potentially determine the rate of decomposition [22,1]. In general, microbes are ubiquitous in nature, while the effectiveness of bacteria depends on their habitat. The habitats with acidic/ anaerobic nature will be the chief carriers of acetogenic/ methanogenic bacteria, while fermentative bacteria are common in most of the habitats. The addition of microbial additives to the digester improves decomposition of the materials. In line with this, the usage of cow dung, agro-industrial and municipal solid wastes as microbial sources were the best practices for efficient biogas production. Consequently, rumen fluid was recognized as a potential source of anaerobic and fermentative bacteria that can be employed as a microbial additive for efficient biogas production.

Table 3. Major microbes and enzymes involved in four stages of anaerobic decomposition.

\begin{tabular}{|c|l|l|}
\hline Stages & \multicolumn{1}{|c|}{ Microorganisms } & \multicolumn{1}{|c|}{$\begin{array}{c}\text { Microbial } \\
\text { Enzymes }\end{array}$} \\
\hline \multirow{3}{*}{ Hydrolysis } & $\begin{array}{l}\text { Bacillus, Streptococcus, } \\
\text { Enterobacter }\end{array}$ & $\begin{array}{l}\text { Cellulase, Protease, } \\
\text { Lipase, Amylase, } \\
\text { Xylanase }\end{array}$ \\
\hline \multirow{3}{*}{ Acidogenesis } & $\begin{array}{l}\text { Micrococcus, } \\
\text { Syntrophomonas, } \\
\text { Pseudomonas, } \\
\text { Flavobacterium, Clostridium, } \\
\text { Acidobacterium }\end{array}$ & $\begin{array}{l}\text { Acetate kinase, } \\
\text { Acetaldehyde } \\
\text { dehydrogenase, } \\
\text { Formate hydrogen } \\
\text { lyase, Formate c- } \\
\text { acetyl transferase }\end{array}$ \\
\hline \multirow{3}{*}{ Methanogenesis } & $\begin{array}{l}\text { Syntrophomonas, Syntrophoba } \\
\text { cter, Clostridium, } \\
\text { Syntrophospora, Acetobacter }\end{array}$ & $\begin{array}{l}\text { Carbonic anhydrase, } \\
\text { Hydrogenases, } \\
\text { Carbon monoxide } \\
\text { dehydrogenases }\end{array}$ \\
& $\begin{array}{l}\text { Methanosarcina, }, \\
\text { Methanosprillum, } \\
\text { Methanococcus, }\end{array}$ & $\begin{array}{l}\text { Methyl co-enzyme } \\
\text { M-transferase, } \\
\text { Methyl co-enzyme } \\
\text { M- reductase, }\end{array}$ \\
& $\begin{array}{l}\text { Methanobrevibacter, } \\
\text { Methanothrix }\end{array}$ & $\begin{array}{l}\text { Formyl } \\
\text { methanofuran } \\
\text { dehydrogenases }\end{array}$ \\
\hline
\end{tabular}


The usage of microbial inoculums with different kinds of microbes that involves in respective stages of anaerobic decomposition revealed improvement in the production of biogas and methane. Thus, the exploration and expansion of significant microbial consortia for biogas production could serve as a prospect for the commercialization of biogas production technology [23].

The co-operation or synchronization of particular microorganisms of four stages is required to achieve complete decomposition. A synchronized action of each kind of microbes is essential since the product of one group of microbes is being the feedstock for the next group of bacteria. While a failure of microbes to utilize the products of the former stage will cause whole process failure. For instance, Methanosarcina barkeri capable of utilizing acetate, carbon dioxide, hydrogen and methanol, but Methanosprillum hungaeti does not utilize acetate but capable of utilize formate. Thus, the production will be lower when using microbes with narrow substrate specificity [24].

Substrate to inoculum ratio is another measure that affects entire decomposition process, hence it is to be maintained to accomplish desirable methane yield. The inoculums to substrate ratio of 1:1-1:3 showed improved methane yield, previously. While, few studies showed smaller inoculum size resulted in highest production [25]. Another prospect for improved biogas production is the identification and employment of potential bacteria for each stage of anaerobic decomposition and its synchronization. The mass production and addition of potential bacteria to respective stages of anaerobic decomposition will enhance the anaerobic decomposition process by reducing the lag period required for the action of a wide range of microbes in the system [26].

\section{Enzymology of anaerobic decomposition}

Enzymes are the biocatalysts involved in all kinds of metabolic reactions. Anaerobic decomposition is the result of complex reactions of various groups of microbial enzymes. However, the enzyme addition could not offer apposite decomposition in contrast to microbial addition. The microbes that has potential to produce diverse degradative enzymes in its utmost concentration are considered as promising candidates for anaerobic decomposition [27]. Diverse microbial enzymes responsible for various stages of anaerobic decomposition is also tabulated in table 3 . The addition of amylase, lipase, protease, etc. showed increased fluidization of materials during anaerobic decomposition. Another investigation explored that the addition of xylanase, cellulase, protease and lipase were effective for solid waste digestion [28]. While enzyme addition to acetogenesis/methanogenesis phase were not accomplished process improvement [29].

Conversely, a mixture of enzymes increased methane production, where the concentration of enzymes applied was an important factor. It is also evidenced that the lowest concentration of $0.5 \mathrm{ml} / \mathrm{kg}$ volatile solids resulted higher degree of decomposition [30]. There were two groups of enzymes involved in initial stage that are lytic enzymes those work cell wall disruption and hydrolytic enzymes that will cause breakdown of the macromolecules. In fact, the pretreatment with enzymes prior to anaerobic decomposition also resulted improved methane production. An increase production of 12-15\% was achieved by enzyme addition to substrates in earlier. A mixture of cellulase and pronase-E showed an $80 \%$ reduction of solids compared to control and 97\% COD removal was observed instead of $63 \%$ of control [31]. Enzymes can act at wide range of environmental conditions such as $\mathrm{pH}$, temperature and salinity; while their utmost action observed at a stable optimum condition. The enzymes are easily accessible by feedstocks rather than the microorganisms. The use of microbes needs lag period for its acclimatization on feedstock, which can be reduced by the direct application of enzymes [32]. Few studies recognized that most of the organism involved in anaerobic decomposition were grown in the range of $\mathrm{pH} 5.5$ to 8.5 . While, the $\mathrm{pH}$ above or below the optimum range could reduce process efficiency. The $\mathrm{pH}$ tends to increase during hydrolysis, followed by decrease during acidogenesis/acetogenesis and again remains in the range of 7.2 to 8.2 when the production of methane stabilizes [33].

\section{Prospects behind various parameters}

Biogas production is influenced by a number of parameters such as feedstock's potential, digester design, inoculum size, substrate nature, $\mathrm{pH}$, temperature, loading rate, hydraulic retention time (HRT), carbon/nitrogen ratio $(\mathrm{C} / \mathrm{N})$, volatile fatty acids (VFA), and so on $[34,26]$. The significant parameters required for digestion process are listed in table 4.

Table 4. Important parameters required for anaerobic digestion.

\begin{tabular}{|c|l|l|}
\hline Parameters & \multicolumn{1}{|c|}{ Modes } & \multicolumn{1}{c|}{ Range } \\
\hline \multirow{4}{*}{ Temperature } & Mesophilic & $30-40^{\circ} \mathrm{C}$ \\
\cline { 2 - 3 } & Thermophilic & $50-60^{\circ} \mathrm{C}$ \\
\hline \multirow{2}{*}{$\mathrm{pH}$} & Hydrolysis & $6.5-7.5$ \\
\cline { 2 - 3 } & Acidogenesis & $5.0-6.5$ \\
\cline { 2 - 3 } & Acetogenesis & $4.0-5.5$ \\
\cline { 2 - 3 } & Methanogenesis & $7.0-8.5$ \\
\hline \multirow{2}{*}{$\begin{array}{c}\text { C/N ratio } \\
\text { acids }\end{array}$} & - & $10-35$ \\
\hline $\begin{array}{c}\text { Loading rate/ } \\
\text { Total solids }\end{array}$ & Small-scale system & $30-300 \mathrm{mg} / 1$ \\
\cline { 2 - 3 } & Large-scale system & $>10 \%$ \\
\hline $\begin{array}{c}\text { Hydraulic } \\
\text { retention time } \\
\text { (HRT) }\end{array}$ & Small-scale system & 30 days \\
\cline { 2 - 3 } & Large-scale system & $30-45$ days \\
\hline
\end{tabular}

\subsection{Temperature}

The psychrophilic $\left(10-30^{\circ} \mathrm{C}\right)$, mesophilic $\left(30-40^{\circ} \mathrm{C}\right)$ and thermophilic $\left(50-60^{\circ} \mathrm{C}\right)$ temperature ranges were feasible for anaerobic digestion while the choice is based on the temperature tolerance of the microorganisms employed. The anaerobic decomposition under thermophilic 
temperature was more powerful than psychrophilic and mesophilic temperature ranges. Few studies revealed that an increase in temperature could significantly improve the performance of anaerobic decomposition system [35,36]. It is also established that mesophilic digestion often causes ammonia inhibition and the rate of inhibition was higher than that of thermophilic degradation [37]. However, a small fluctuation in thermophilic temperature would detrimentally affect the whole system and it implies that the maintenance of temperature is imperative to achieve stable digestion [38]. A sewage sludge mesophilic system with a total solid concentration of $10 \%$ showed desirable production whereas $7.5 \%$ total solid concentration was required for thermophilic system [39]. Thus, an increase in temperature $\left(50-65^{\circ} \mathrm{C}\right)$ improves the rate of anaerobic decomposition and also higher metabolic rates were observed in thermophilic condition. However, the effortless management and ideal biogas production are the considerable features of mesophilic systems.

\subsection{Volatile fatty acids and $\mathrm{pH}$}

The typical intermediates of anaerobic decomposition are long-chain/ short-chain volatile fatty acids that includes acetic acid, propionic acid, butyric acid, valeric acid, etc., where propionate and acetate take part the dominant portion. Since, the ratio of propionate to acetate can be used as the indicator of the process progress [40]. During acetogenesis, long-chain fatty acids are converted to short chain fatty acids or acetate by $\beta$ - oxidation process. There is a probability of accumulation of long-chain fatty acids once it is not converted successfully or even due to the accumulation of acetate when it is formed excessively. The accumulation of volatile fatty acids can be evaded through certain approaches, either by maintaining the optimum solid content of the system nor by supplying effective inoculums with adequate ratio. Otherwise, the addition of adsorbents also showed admirable effect to neutralize volatile acids [30]. The ion-exclusion, HPLC and gas chromatography are usually employed methods for the analysis of volatile fatty acids concentration in the system.

The $\mathrm{pH}$ concentration of the system principally allied with the concentration of volatile fatty acids exhibited. Usually, a pH range of 4.0 to 7.5 is favourable for fermentative degradation while a $\mathrm{pH}$ of 7.0 to 8.5 is feasible for methanogenic bacteria [7]. The accumulation of volatile fatty acids especially butyrate and acetate lead to decrease in $\mathrm{pH}$ that causes adverse effect on microbial growth and process unsteadiness occurs. On the other hand, the excessive bioconversion of short-chain fatty acids leads to the accumulation of ammonia and as a result $\mathrm{pH}$ increases over 8.5, that inhibit methanogenesis. The excess or high concentrations of long chain fatty acids will inhibit the growth of methanogens by damaging the cellular membrane [41]. Though it is assigned that the bacterial population can be maintained by controlling $\mathrm{pH}$ of the system. The long chain fatty acid concentration of about 30-300 mg/l was found as appropriate for anaerobic decomposition [42]. The effluent and some additives were found as suitable to neutralize volatile fatty acids in many systems. Moreover, $\mathrm{pH}$, temperature, volatile fatty acids, $\mathrm{H}_{2}$ partial pressure, ammonia accumulation and heavy organic loading were the foremost parameters that causes process unsteadiness, is tabulated in table $5[43,8]$.

\subsection{Carbon/nitrogen $(\mathrm{C} / \mathrm{N})$ ratio}

The Carbon/Nitrogen $(\mathrm{C} / \mathrm{N})$ ratio is another important factor that determines the decomposition rate and biogas production. Based on the carbon and nitrogen content, biomass can be distinguished in to carbon or nitrogen rich and carbon or nitrogen low materials. Usually microbes utilize carbon much faster than nitrogen. Hence the carbon content should be many folds higher than that of nitrogen content [44]. A carbon/nitrogen $(\mathrm{C} / \mathrm{N})$ ratio of 10-35 was established as optimum for maximum biomass degradation. An increase in $\mathrm{C} / \mathrm{N}$ ratio causes increased uptake of carbon and thereby accumulation of volatile fatty acids occurs. The lower $\mathrm{C} / \mathrm{N}$ ratio causes enhanced nitrogen uptake and thereby ammonia accumulation partakes. However, the optimization of carbon and nitrogen ratio of substrate reduces the accumulation of volatile fatty acids and ammonia.

Recent studies explored that co-digestion of two or more substrates assist to maintain $\mathrm{C} / \mathrm{N}$ ratio and thereby reduce accumulation of inhibitors [45]. The advantages of co-digestion are it offers optimum $\mathrm{C} / \mathrm{N}$ ratio, wide range substrate availability, better degradability, improved methane/biogas production, low energy requirement, utilization of complex substrates, highly nutrient biofertilizer, etc. Nowadays, co-digestion of lignocellulosic agricultural wastes or industrial wastes with animal manures become a new trend to enhance its degradability, instead of using alone. Co-digestion do not possess any positive impact on reducing hydraulic retention time, but increases the decomposition rate as well as biogas production [46].

\subsection{Hydraulic retention time (HRT)}

The hydraulic retention time (HRT) is the time taken to carry out the whole process. The small-scale systems generally work with low organic loading rate below $10 \%$. For the industrial scale production, organic loading rate is the major measure and moderate/high organic rate is desirable to assure economical progression. Generally, high organic loading rate will cause process unsteadiness sometimes process failure, which needs long HRT. Hence further improvements are needed through microbial addition or other methods to improve organic loading rate and to reduce low HRT [47]. An effort has been made by Divya et al in 2019 through enzyme addition, that resulted significant reduction of HRT from 30 days to 20 days [9]. The HRT can be measured by using certain criteria with the aid of following equation (1). It is expressed in hours (d), where $\mathrm{V}$ is the volume of aeration tank (m3) and Q is the influent flow rate $\left(\mathrm{m}^{3} / \mathrm{d}\right)$ [48].

$$
\operatorname{HRT}(\mathrm{d})=\mathrm{V} / \mathrm{Q}
$$




\subsection{Metal elements}

In addition to nutrients, the light metal ions $(\mathrm{Na}, \mathrm{Mg}, \mathrm{Al}$, $\mathrm{Ca}, \mathrm{K})$ and heavy metal ions ( $\mathrm{Co}, \mathrm{Cr}, \mathrm{Ni}, \mathrm{Zn}, \mathrm{Cu}$, etc.) are also necessitate for decomposition since which play a significant role in the production of degradative enzymes along with maintaining enzyme activities [49,50]. Even though some side effects caused by the presence of heavy metals in the feedstock are described here. Heavy metals are not easily degradable and would accumulate during decomposition that leads to process inhibition. The factors influencing metal accumulation are total concentration of metals, $\mathrm{pH}$ and redox potential. The accumulation of sodium and potassium was reported as the prime issue and co-digestion approaches are admirable to overcome these kinds of inhibition [51].

Many studies evidenced that the heavy metals $\mathrm{Cr}$, $\mathrm{Cd}$ and $\mathrm{Ni}$ are highly toxic, that disrupt enzyme activity in large extent. Besides that, $\mathrm{Zn}, \mathrm{Cu}, \mathrm{Pb}$ and $\mathrm{Fe}$ showed inhibitory effect under certain conditions. The effect of heavy metals in decomposition is usually occur in the increasing order of $\mathrm{Pb}<\mathrm{Zn}<\mathrm{Cu}<\mathrm{Cd}$. The heavy metals possess chemical binding to the enzymes and makes changes in the orientation of enzyme. Although, the inhibitory effect of metals to microbes is based on its concentration, types of microbes and microbial resistance power over it. Since advanced research is necessary to identify the effect of various heavy metals on acetogenic and methanogenic stages of anaerobic decomposition [52].

\section{Anaerobic bioreactor models}

The anaerobic bioreactors are mainly classified in to three types based on the mode of treatments, reactor type and segregation of stages cast-off (Figure 8). The different reactor models frequently employed for biogas production process through oxygen free decomposition are presented below.

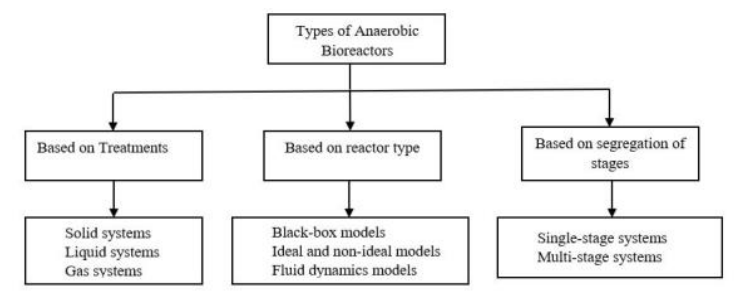

Fig. 8. Different types of anaerobic bioreactors for biogas production

\subsection{Solid, liquid and gas phase systems}

Based on the type of treatments used in bioreactor, they are classified in to solid phase system, liquid phase system and gas phase system. The solid phase system works with solid/sludge granules with a diameter of about 0.5-2.0 $\mathrm{mm}$. The liquid phase systems are usually run with waste water, where the lower part contains sludge bed while the upper part contains solid, liquid and gas phases. Solid phase and liquid phase systems are generally used for treating organic wastes, which ensures biogas production once required. Nevertheless, gas phase systems are typically used for biogas production only, where organic materials such as dead plant and animal materials, animal feces, agro-industrial wastes, domestic wastes, etc. can be used for biomethanation.

\subsection{Promising bioreactor models}

Based on the type of reactors used, they are classified in to black-box models, phenomenological models (ideal and non-ideal models) and computational fluid dynamics models. The artificial neural networks are coming under black-box model that do not require knowledge concerning the key intermediates of anaerobic decomposition systems. The ideal models include continuous stirred tank reactors (CSTR) and plug flow reactor (PFR). CSTR can be used for treating complex materials in a continuous mode, which offers better decomposition too. Plug flow reactor and plug flow with dispersion reactor models were developed to treat organic wastes in stimulation mode [53]. Few digester models designed through comprehensive approach by CSTR and PFR configuration were found as non-ideal models that would assist improved anaerobic decomposition, which possess stirring device and optimization properties [54]. Computational fluid dynamic (CFD) model is a simulation approach to optimize parameters to improve the performance of the system. However, it is established that in-silico model simulation approaches are desirable to enhance the rate of decomposition through suitable mathematical modeling.

\subsection{Single stage and multi-stage systems}

The anaerobic digestion systems are distinguished into single stage and multi-stage systems based on the segregation of different stages. Single stage systems are usually used for past many decades where the decomposition carried out in a single system with batch or continuous mode. In single stage batch reactors, all the four steps of anaerobic digestion put together and as a result process unsteadiness or low biogas production occurs by the improper maintenance of optimum parameters of four stages. Multi-stage systems with the separation of acidogenesis and methanogenesis showed improved gas production in earlier. Lyberatos and Skiadas in 1999 proposed several mathematical models for improving biogas production [8]. They demonstrated that volatile fatty acids accumulation and $\mathrm{pH}$ changes are the major reasons that causes process unsteadiness. Moreover, it is presumed that separation of each of the four stages of anaerobic decomposition would improve substrate degradation as well as biogas/methane production [26]. The segregation of each of the four stages within a digester by specific microbial addition or enzyme addition along with optimum parameters, is a promising challenge to enhance methane production in future. 


\section{Future of biogas production}

Biochemical methane potential is the measure to find out methane potential of diverse organic materials prior to anaerobic decomposition and according to that potent materials can be selected as best choice for the biogas production purpose. The substrate selection based on its availability throughout the year is another factor that offers continuous production and lead to commercialization of biogas as an alternative to nonrenewable conventional energy sources. The socioeconomic impacts such as biofertilizer production and materials recycling are the emerging challenges of this eco-friendly technology that can be potentially used for making a greener tomorrow by reducing environmental pollution. Co-digestion of different probable organic materials by maintaining $\mathrm{C} / \mathrm{N}$ ratio propose improved substrate decomposition and biogas/methane production. Biological pretreatment of complex substrates prior to anaerobic decomposition is a promising prospect to increase the availability of nutrient rich substrates.

The optimization of specific parameters such as temperature, $\mathrm{pH}$, organic loading rate, total solids, etc. would also augment biogas production. The analysis of $\mathrm{pH}$, temperature, volatile solid content, chemical oxygen demand and volatile fatty acids during decomposition could benefit to trace out the rate of decomposition. Moreover, appropriate measures should be taken to maintain all imperative parameters like $\mathrm{pH}$, temperature and volatile fatty acids concentration throughout the process. The digester design plays a significant role in maintaining the rate of decomposition. Digesters with all control measures to neutralize the fluctuations in parameters possess high economic impact. In line with this, the implementation of continuous stirred tank systems over batch systems with thermometer, digital $\mathrm{pH}$ analyser, pressure gauge, sampling unit, inlet, outlet, stirrer, gas jacket, etc. will be more convenient and significant for the effective process monitoring and controlling.

Conversely, multi-stage digesters are desirable for realizing maximum substrate decomposition. Segregation of anaerobic digestion in single stage system through microbial means by providing optimum conditions would be another task in this field. The microbial and enzyme addition also helps to improve substrate decomposition. Further exploration is needed to identify potential strains and to analyze enzyme stability in order to augment its utilization. The development of genetically modified anaerobic microbes is a great challenge in this area while that requires advanced techniques to overcome the highly sensitive nature of anaerobic bacteria. In this scenario, the implementation and usage of effective microbial consortia partaking high decomposition rate is another viable perspective [23]. Even though some techniques have been executed to purify the biogas for concentrating methane content. There is a need for cost-effective technologies for purification of biogas to enrich the methane concentration and thereby to increase flammability as well as its competence towards conventional energy sources.

\section{Conclusion}

Biogas production from biomass is an eco-friendly method that offers energy generation along with maintaining environmental standards. The exploration and utilization of various complex, potential biomass along with pretreatment, microbial/enzyme addition, parameters maintenance and process segregation are necessary for sustainable utilization of biomass for absolute biogas production. Moreover, cost-effective, small-scale anaerobic digestion systems with specific control measures are adequate at the moment to commercialize this technology. Hence, this study suggests that comprehensive approaches with such forecasts are admirable to extend the utility of diverse biomass to meet today's energy demand in sustainable means.

\section{Acknowledgement}

The authors acknowledge the Rohini College of Engineering and Technology, Vivekanandha College of Arts and Sciences for Women, and Pinnacle Bio-Sciences for providing research support to carry out this review work. The authors also acknowledge the Natural Composites Research Group Lab, Department of Materials and Production Engineering, The Sirindhorn International Thai-German Graduate School of Engineering, King Mongkut's 13 University of Technology North Bangkok, Bangkok-10800, Thailand. for their support to complete this review article.

\section{References}

1. P. Merlin Christy, L. R. Gopinath, D. Divya, A review on anaerobic decomposition and enhancement of biogas production through enzymes and microorganisms. Elsevier- Renewable and Sustainable Energy Reviews, 34 (2014): 167-173.

2. CEA, MNRE, Mercom India Solar Project Tracker, source: Mercom India Research, Installed Capacity and Capacity Utilization as on 31 Mar 2020, (2020).

3. S.Z.Bibi, M. Qaisar, P. Arshid, Characteristics and Performance of Anaerobic Wastewater Treatment (A Review), Journal of the Chemical Society of Pakistan., 35, 1 (2013): 217-232

4. Y. Voegeli, C. Zurbrügg, Decentralised anaerobic digestion of kitchen and market waste in developing countries - "state-of-the-art" in south India, Proceedings Venice 2008, Second International Symposium on Energy from Biomass and Waste Venice, Environmental Sanitary Engineering Centre, Italy, 17-20 November 2008.

5. P. Valerio, P. Francesco, S. Marco, T. Laura, N. Naja, C. Angelo, Environmental impact of biogas: A short review of current knowledge, Journal of Environmental Science and Health, Part A, 53, 10 (2018), 899-906

6. O.S. Joshua, G.J. Ejura, I.C. Bako, I.S. Gbaja, Y.I. Yusuf, Fundamental principles of biogas product, 
International Journal of Scientific Engineering and Research, 2, 8 (2014): 47-50.

7. D. Divya, L. R. Gopinath, P. Merlin Christy, A review on Trends, Issues and Prospects for biogas production in Developing Countries, International Research Journal of Environmental Sciences, 3, 1 (2014): 62-69.

8. G. Lyberatos, I.V. Skiadas, Modeling of anaerobic digestion- a review. Global Nest: The international Journal, 1, 2 (1999): 63-76.

9. D. Divya, L. R. Gopinath, S. Indran, Analysis of the effect of enzyme substitution on feedstock to enhance biogas production, International Journal of Research and Analytical Reviews, 6, 2 (2019): 964-973.

10. Asian Biomass Handbook, Part 2, Biomass resources, University of Tokyo, Japan (2008).

11. D. Divya, L. R. Gopinath, S. Sreeremya, S. Indran, Enhancement of Substrate Decomposition through Potential Hydrolytic Bacteria for Cumulative Biogas Production, International Journal of Applied Science and Biotechnology, 6, 4 (2018): 386-396.

12. D.O. Hall, F. Rosillo-Calle, R.H. Williams, J. Woods, Biomass for energy: supply prospects, in Renewable Energy: Sources for Fuels and Electricity, (ed.) Johansson, T.B., Kelly, H., Reddy, A.K.N., and Williams, R.H., Washington, DC, Island Press, (1998): 593- 651.

13. P.C. Suryawanshi, A.B. Chudhari, S. Bhardwaj, T.Y. Yeole, T.Y. Operating procedures for efficient anaerobic digester operation. Research Journal of Animal, Veterninary and Animal Sciences ; Fishery Sciences, 1, 2 (2013): 12-15.

14. S. Aliyu and A. Zahangir, Pretreatment Methods of Organic Wastes for Biogas Production, Journal of Applied Sciences., 16 (3) (2016): 124-137

15. A. Javkhlan Ariunbaatar, P. Antonio, E. Giovanni, P. Francesco, N.L.L. Piet, Pretreatment methods to enhance anaerobic digestion of organic solid waste, Applied Energy, 123, 15 (2014): 143-156

16. H.B. Gonzales, K. Takyu, H. Sakashita, Y. Nakano, W. Nishijima, M. Okada, Biological solubilization and mineralization as novel approach for the pretreatment of food waste, Chemosphere, 58 (2005): 57-63.

17. J.W. Lim, J.Y. Wang, Enhanced hydrolysis and methane yield by applying microaeration pretreatment to the anaerobic co-digestion of brown water and food water, Waste Management, 33 (2013): 813-819.

18. G.D. Saratale, S.D. Chen, Y.C. Lo, R.G. Saratale, J.S. Chang, Outlook of biohydrogen production from lignocellulosic feedstock using dark fermentation- A review, Journal of Scientific and Industrial Research, ,67 (2008): 962-979.

19. F.R. Lucy, Pretreatment of feedstock for enhanced biogas production, IEA Bioenergy, First edition books, (2014).
20. J. Perez, J. Munoz-Dorado, T. Rubia, J. Martinez, Biodegradation and biological treatments of cellulose, hemicelluloses and lignin: An overview, International Journal of Microbiology, 5 (2002): 5363.

21. U.G. Phutela, N. Sahni, S.S. Sooch, Fungal degradation of paddy straw for enhancing biogas production, Indian Journal of Science and Technology, 4, 6 (2011): 660-665.

22. R. Manimegalai, L. R. Gopinath, P. Merlin Christy, D. Divya. Isolation and identification of acetogenic and methanogenic bacteria from anoxic black sediments and their role in biogas production, International Journal of Plant, Animal \& Environmental Sciences, 4, 3 (2014): 156-164.

23. L. R. Gopinath, P. Merlin Christy, K. Mahesh, R. Bhuvaneswari, D. Divya, Identification and evaluation of effective bacterial consortia for efficient biogas production, IOSR Journal of Environmental Science, Toxicology and Food Technology, 8, 3 (2014): 82-86.

24. I.O. Okonko, O.T. Adeola, F.E. Aloysius, A.O. Damiola, O.A. Adewale, Utilization of food wastesfor sustainable development, Electronic Journal of Environmental Agricultural and Food Chemistry, 8, 4 (2009): 263-286.

25. A.S. Fayyaz, M. Qaisar, M.H. Mohammad, P. Arshid, A.A. Saeed, Microbial ecology of anaerobic digesters: The key players of Anaerobiosis, The Scientific World Journal, (2014): 1-21.

26. D. Divya, L. R. Gopinath, P. Merlin Christy, A review on current aspects and diverse prospects for enhancing biogas production in sustainable means, Renewable and Sustainable Energy Reviews, 42 (2015a): 690-699.

27. W. Parawira, Enzyme research and applications in biotechnological intensification of biogas production, Critical Reviews in Biotechnology, (2011): 1-15.

28. J. Rintala, B. Ahring, Thermophilic anaerobic digestion of source-sorted households solid waste: the effects of enzyme additions, Applied Microbiology and Biotechnology, 40 (1994): 916919.

29. J. Jeganathan, G. Nakhla, A. Bassi, Hydrolytic pretreatment of oily waste water by immobilized lipase, Journal of Hazardous Materials, 145 (2007): 127-135.

30. C. Zhang, H. Su, J. Baeyens, T. Tan, Reviewing the anaerobic digestion of food waste for biogas production, Renewable and Sustainable Energy Reviews, 38 (2014): 383-392.

31. H.J. Roman, J.E. Burgess, B.I. Pletschke, Enzyme treatment to decrease solids and improve digestion of primary sewage sludge, African Journal of. Biotechnology, 5 (2006): 963-967. 
32. S.K. Ahuja, G.M. Ferreira, A.R. Moreira, Utilization of enzymes for environmental applications, Critical Reviews in Biotechnology, 24 (2004): 125-154.

33. T. Abbasi, S.M. Tauseef, A. Abbasi, Anaerobic digestion for global warming control and energy generation- An overview, Renewable and Journal of Plant, Animal and Environmental Sciences, 3, 4 (2013): 65-70.

34. P. Merlin Christy, L. R. Gopinath, D. Divya. A review on decomposition as a technology for sustainable energy management, International Sustainable Energy Reviews, 16, 5 (2012): 32283242.

35. H.M. Ei- Mashad, G. Zeeman, W.K.P. Van Loon, G.P.A. Bot, G. Lettinga, Effect of temperature fluctuation on thermophilic anaerobic digestion of cattle manure, Bioresource Technology, 95 (2004): 191-201.

36. E. Sanchez, R. Borja, P. Weiland, L. Travieso, A. Martin, Effect of substrate concentration and temperature on the anaerobic digestion of piggery waste in a tropical climate, Process Biochemistry, 37 (2001): 483-489.

37. C. Gallert, S. Bauer, J. Winter, Effect of ammonia on the anaerobic degradation of protein by mesophilic and thermophilic biowaste, Applied Microbiology and Biotechnology, 50 (1998): 495-501.

38. I. Apples, A.V. Assche, K. Willems, J. Degreve, J.V. Impe, R. Dewil, Peracetic acid oxidation as an alternative pre-treatment for the anaerobic digestion of waste activated sludge, Bioresource Technology, 102 (2011): 4124-4130.

39. T. Hidaka, F. Wang, T. Pascual, Comparative performance of mesophilic and thermophilic anaerobic digestion for high solid sewage sludge, Bioresource Technology, 149 (2013): 177-183.

40. U. Marchaim, C. Krause, Propionic to acetic acid ratios in overloaded anaerobic digestion. Bioresource Technology, 43 (1993): 195-203.

41. I. Angelidaki, B.K. Ahring, Effects of free long-chain fatty acids on thermophilic anaerobic digestion, Applied Microbiology and Biotechnology, 37 (1992): 808-812.

42. A. Fernández, A. Sánchez, X. Font, Anaerobic codigestion of a simulated organic fraction of municipal solid wastes and fats of animal and vegetable origin, Biochemical Engineering Journal, 26, 1 (2005): 2228.

43. J. F. Andrews, Dynamic Model of the Anaerobic Digestion Process, Journal of the Sanitary Engineering Division, 1 (1969): 95-116.

44. P. Mahanta, U.K. Saha, A. Dewan, P. Kalita, B. Buragohain, Biogas digester: A discussion on factors affecting biogas production and field investigation of a novel duplex digester, Journal of the Solar Energy Society of India, 15, 2 (2005): 1-12.
45. S. Park, Y. Li, Evaluation of methane production and macronutrient degradation in the anaerobic codigestion of algae biomass residue and lipid waste, Bioresource Technology, 111 (2012): 42-48.

46. D. Divya, L. R. Gopinath, S. Indran, P. Merlin Christy, Enhancement of biogas production through sustainable feedstock utilization by co-digestion, International Journal of Plant, Animal and Environmental Sciences, 5, 3 (2015b): 88-94.

47. A. Award, C. Xiaoguang, L. Jianshe, X. Xuehui, Z. Jian, Z. Kai, W. Heng, L. Na, Characteristics, process parameters, and inner components of anaerobic bioreactors, Biomed Research International, (2014): $1-10$.

48. M.T. Kato, J.A. Field, R. Kleerebezem, G. Lettinga, Treatment of low strength soluble wastewaters in UASB reactors. Journ. Journal of Fermentation and Bioengineering., 77 (1994): 679.

49. I. Zhang, Y.W. Lee, D. Jhang, Anaerobic codigestion of food waste and piggery waste water: focusing on the role of trace elements, Bioresource Technology, 102 (2011): 5048-5059.

50. A. Schattauer, E. Abdoun, P. Weiland, M. Plochl, M. Heiermann, Abundance of trace elements in demonstration biogas plants, Biosystem Engineering, 108 (2011): 57-65.

51. F. Cheng, K. Boe, A. Irini, Anaerobic co-digestion of desugared molasses with cow manure focusing on sodium and potassium inhibition, Bioresource Technology, 102 (2011): 1005-1011.

52. A. Mudhoo, S. Kumar, Effects of heavy metals as stress factors on anaerobic digestion processes and biogas production from biomass, International Journal of Environmental Science and Technology, 10 (2013): 1383-1398.

53. P. Buffiere, C. Fonade, R. Moletta, Mixing and phase hold-ups variations due to gas production in anaerobic fluidized-bed digesters: influence on reactor performance, Biotechnology and Bioengineering, 60 (1998): 36-43.

54. L. Yu, P.C. Wensel, J. Ma, S. Chen, Mathematical modeling in Anaerobic decomposition, Bioremediation and Biodegradation, S4 (2013): 003. 